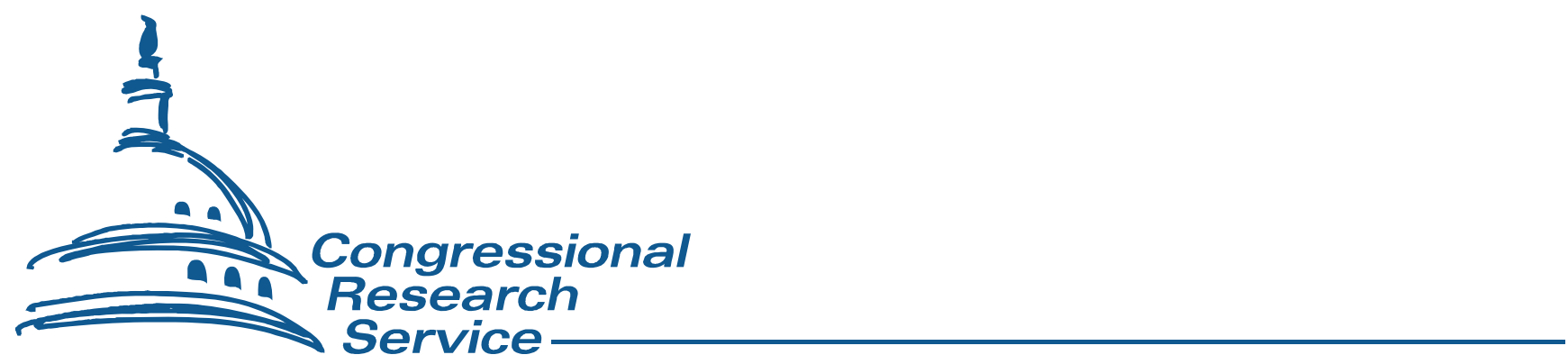

\title{
School Finance Litigation
}

Jody Feder

Legislative Attorney

January 15, 2009

Congressional Research Service 


\section{Summary}

Over the past several decades, a series of lawsuits have challenged funding disparities that exist among school districts within the states. Spurred by concerns that such disparities discriminated against students in poor school districts or resulted in an inadequate education, school finance plaintiffs began filing lawsuits in federal and state courts based on theories involving educational equity or adequacy. This report provides an analysis of litigation regarding school financing, including an overview of the legal issues involved in such litigation and a description of the leading school finance cases at both the federal and state level. 


\section{Contents}

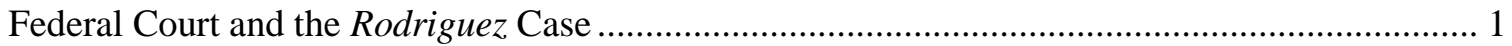

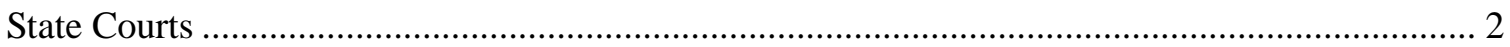

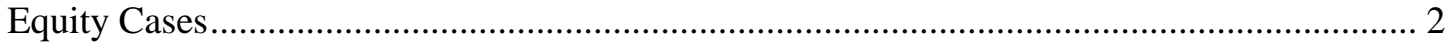

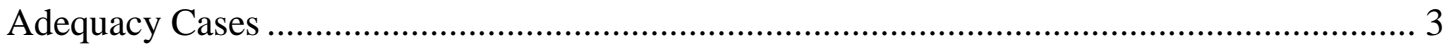

\section{Contacts}

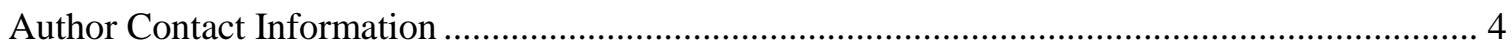


$\mathrm{I}$

$\mathrm{n}$ the 1970s, a series of lawsuits began challenging the funding disparities among school districts within the states. ${ }^{1}$ Schools in the U.S., which typically receive some federal and state financial assistance, generally derive a substantial percentage of their funding from local property taxes, which, at least in the early days of education finance litigation, generated significantly different levels of funding depending on how much the property in a given district was worth. Spurred by concerns that such disparities discriminated against students in poor school districts or resulted in an inadequate education, school finance plaintiffs began filing lawsuits in federal and state courts based on theories involving educational equity or adequacy. ${ }^{2}$

In the most prominent federal case on school financing, San Antonio Independent School District v. Rodriguez, ${ }^{3}$ the Supreme Court rejected a legal challenge to Texas's system of public financing for its elementary and secondary schools, holding that the state finance system did not violate equal protection or interfere with a fundamental right. Ultimately, the Rodriguez case, which clarified that school funding disparities were not a federal issue, foreclosed school finance claims based on the U.S. Constitution and prompted plaintiffs to file lawsuits based on state constitutional claims, thereby transforming education finance litigation into an issue of state law. This memorandum discusses the Rodriguez case and the resulting flurry of state education finance litigation, including the dominant legal theories of equity and adequacy and the leading cases in each of these areas.

\section{Federal Court and the Rodriguez Case}

In Rodriguez, the original plaintiffs in the case challenged the Texas state system of public financing for elementary and secondary schools, which they claimed to be a violation of the Equal Protection Clause of the Fourteenth Amendment ${ }^{4}$ because funding under the system, which was based on local property taxes, discriminated against students in less affluent school districts and interfered with the students' fundamental right to education. The Supreme Court rejected both of these arguments, holding that the state finance system did not violate equal protection or interfere with a fundamental right. ${ }^{5}$

Under the Supreme Court's equal protection jurisprudence, "the general rule is that legislation is presumed to be valid and will be sustained if the classification drawn by the statute is rationally

\footnotetext{
${ }^{1}$ For general information on school finance litigation, see the National Access Network at http://www.schoolfunding.info/litigation/litigation.php3; the Education Commission of the States at http://www.ecs.org/; and the Department of Education's National Center for Education Statistics at http://nces.ed.gov/ EDFIN/litigation.asp. See also, EQUITY AND ADEQUACY IN EDUCATION FinANCE: Issues AND PERSPECTIVES (Helen F. Ladd et al. eds. 1999); Michael A. Rebell, Education Adequacy, Democracy and the Courts (April 25, 2001), http://www.schoolfunding.info/resource_center/research/adequacychapter.pdf.

${ }^{2}$ A handful of lawsuits have claimed that state education finance systems violate Title VI of the Civil Rights Act, which prohibits discrimination on the basis of race, color, or national origin in programs receiving federal financial assistance. See, e.g., Robinson v. Kansas, 295 F.3d 1183 (10 ${ }^{\text {th }}$ Cir. 2002); Powell v. Ridge, 189 F.3d 387 ( $3^{\text {rd }}$ Cir. 1999).

${ }^{3} 411$ U.S. 1 (1973).

${ }^{4}$ Section 1 of the Fourteenth Amendment states in relevant part: "No State shall make or enforce any law which shall abridge the privileges or immunities of citizens of the United States; nor shall any State deprive any person of life, liberty, or property without due process of law; nor deny to any person within its jurisdiction the equal protection of the laws.” U.S. Const. amend. XIV, § 1.

${ }^{5}$ San Antonio Indep. Sch. Dist. v. Rodriguez, 411 U.S. 1, 18 (1973).
} 
related to a legitimate state interest," although laws that are based on suspect classifications such as race or gender or that interfere with a fundamental right typically receive heightened scrutiny and require a stronger, if not compelling, state interest to justify the classification or infringement. The Rodriguez Court, however, concluded that the Texas financing system did not discriminate against any definable category of poor people or result in the absolute deprivation of education and therefore held that there was no impermissible classification based on wealth and no discrimination against a suspect class. ${ }^{7}$ Likewise, the Court found that the Constitution did not explicitly or implicitly guarantee a right to education and that there was no evidence that the Texas financing system resulted in an education so inadequate that it interfered with the ability to exercise other fundamental constitutional rights. ${ }^{8}$

The Court's holding that there was no discrimination against a suspect class and no interference with a fundamental right was important because it determined the degree of judicial scrutiny that the Texas financing system received. Had the Court found a violation of equal protection or infringement of a fundamental right, then the Texas school funding system would have been subject to strict scrutiny and the state would have been required to offer a compelling state interest as justification for the system. In the absence of such a finding, however, the Texas financing system was subject to rational basis review. Under that standard, the Court upheld the state funding system as rationally related to the legitimate state interest of maintaining local control over matters involving education and taxation. ${ }^{9}$

\section{State Courts}

As noted above, the Rodriguez case foreclosed school finance claims based on the federal constitution and prompted plaintiffs to file lawsuits based on state constitutional claims instead, thereby transforming education finance litigation into an issue of state law. This section discusses the two major legal theories involved in state education finance litigation-equity and adequacy_as well as leading cases in these areas.

\section{Equity Cases}

Initially, litigants in school finance cases focused on the issue of equity. Arguing that the funding disparities among school districts were inequitable, the plaintiffs in these cases contended that such inequities were unconstitutional and should be remedied by equalizing funding among all school districts. Although the U.S. Supreme Court had rejected arguments based on the Equal Protection Clause of the U.S. Constitution, advocates for school financing reform typically based their new legal claims on equal protection provisions found within the constitutions of individual states. For example, in Serrano v. Priest, which is the most prominent example of an equity-based education finance claim, the Supreme Court of California held that the state finance system for public schools violated the equal protection provisions in the California constitution because

\footnotetext{
${ }^{6}$ City of Cleburne v. Cleburne Living Center, 473 U.S. 432, 440 (1985).

${ }^{7}$ Rodriguez, 411 U.S. at 25, 28.

${ }^{8}$ Id. at 35-37.

${ }^{9}$ Rodriguez, 411 U.S. at 50-56.
} 
"discrimination in educational opportunity on the basis of district wealth involves a suspect classification, and ... education is a fundamental interest." 10

Although an equity-based litigation strategy was effective in some of the early cases:

[The] difficulties of actually achieving equal educational opportunity through the fiscal neutrality principle, as well as political resistance to judicial attempts to enforce court orders in the initial fiscal equity cases, seem to have dissuaded other state courts from venturing down this path. Despite an initial flurry of pro-plaintiff decisions in the mid-1970s, by the mid-1980's, the pendulum had decisively swung the other way: plaintiffs won only two decisions in the early ' 80 s, and, as of $1988 \ldots 15$ of the State Supreme Courts had denied any relief to the plaintiffs ... compared to the seven states in which plaintiffs had prevailed. ${ }^{11}$

In part, this shift may have occurred because state courts and legislatures experienced implementation difficulties when attempting to equalize funding among school districts and because court decisions that required equal resources did not necessarily ensure equal or adequate educational opportunities. ${ }^{12}$ As a result of this diminished success with equity-based claims, plaintiffs in school financing cases began bringing school finance claims based on adequacy theories instead.

\section{Adequacy Cases}

Although state courts continued to analyze education finance cases in terms of equal protection, the courts gradually began to examine other considerations, notably arguments regarding educational adequacy. Specifically, rather than rely on the argument that school funding disparities were a violation of equal protection, some plaintiffs began arguing that inadequate funding levels resulted in a violation of state constitutional provisions that guaranteed an adequate education. Most of these claims were based on provisions found in virtually all state constitutions that require states to establish a system of free public schools and provide students with a "thorough," "efficient," or "adequate" education. ${ }^{13}$

For example, in the early case Robinson v. Cahill, the Supreme Court of New Jersey interpreted a state constitutional provision that required the legislature to provide for "a thorough and efficient system of free public schools," and the court concluded that "we do not doubt than an equal educational opportunity for children was precisely in mind" and "the obligation is the State's to rectify." 14 As a result, the court ruled that the New Jersey school finance system was unconstitutional but left it to the legislature to devise a solution that would compel localities to provide equal educational opportunities to their students. In another significant adequacy case, Rose v. Council for Better Education, the Supreme Court of Kentucky evaluated the claim that the state education financing scheme was inadequate and therefore a violation of a state constitutional provision that requires the legislature to "provide for an efficient system of common schools." 15

\footnotetext{
${ }^{10} 557$ P.2d 929, 951 (Cal. 1976).

${ }^{11}$ Rebell, supra footnote 1, at 24.

${ }^{12}$ Rebell, supra footnote 1, at 21-23.

${ }^{13}$ Kindle Merrell, Education Commission of the States, Constitutional Language: State Obligations for Public School Funding (August 2002), http://www.ecs.org/clearinghouse/38/62/3862.htm.

14303 A. 2d 273, 294 (N.J. 1973).

15790 S.W.2d 186 (Ky. 1989).
} 
The court not only found such a violation, but held that "Kentucky's entire system of common schools is unconstitutional" "because the entire system is "underfunded and inadequate" and "fraught with inequalities and inequities." 17 The court then held that every child "must be provided with an equal opportunity to have an adequate education" and set forth educational standards to define what constitutes an adequate education. ${ }^{18}$

Currently, state education finance litigation typically involves adequacy-based claims. As one commentator notes, "Adequacy has become the predominant theme of the recent wave of state court decisions because the adequacy approach resolves many of the legal problems that had arisen in the early fiscal equity cases and because it provides the courts judicially manageable standards for implementing effective remedies." ${ }^{.19}$ Regardless of whether such lawsuits involve equity or adequacy theories, education finance litigation has thus far been brought in 45 out of 50 states. $^{20}$

\section{Author Contact Information}

Jody Feder

Legislative Attorney

jfeder@crs.loc.gov, 7-8088

${ }^{16} I d$. at 215.

${ }^{17}$ Id. at 197.

${ }^{18} I d$. at 211-12. For a discussion of how adequacy litigation is linked to the rise in the standards-based educational reform movement, see generally Rebell, supra footnote 1 .

${ }^{19} I d$. at 36.

${ }^{20}$ Detailed tracking or analysis of state litigation is beyond the scope of this report. For more information on such litigation, see the National Access Network's website at http://www.schoolfunding.info/litigation/litigation.php3. 